\title{
Non-Regional Lymph Node New Tumor
}

\section{Event}

National Cancer Institute

\section{Source}

National Cancer Institute. Non-Regional Lymph Node New Tumor Event. NCI Thesaurus.

Code C160424.

Lymph nodes located outside the region of interest. 